\title{
Planting Cabbage to a Stand with Precision Seeding
}

\author{
Regina P. Bracy, Richard L. Parish', Paul E. Bergeron², E.B. Moser, \\ and R. J. Constantin \\ Hammond Research Station, Louisiana Agricultural Experiment Station, \\ Louisiana State University Agricultural Center, 5925 Old Covington Highway, \\ Hammond, LA 70403
}

\begin{abstract}
Additional index words. Brassica oleracea, plant spacing, within-row spacing, stand thinning, stand establishment
\end{abstract}

\begin{abstract}
Field studies were conducted in Spring 1989 and 1990 to determine if cabbage (Brassica oleracea L. Capitata Group) could be precision-seeded to a stand without subsequent thinning and to determine the optimum seed spacing necessary to seed cabbage directly to a stand. Seed spacings of 10,20 , and $30 \mathrm{~cm}$ at one seed per hill and $30 \mathrm{~cm}$ at two seeds per hill were evaluated for effect on yield, head weight, plant population, and harvest percentage. Seeder precision (accuracy) with regard to seed counts and spacing measurements at the various seed spacings, as evaluated in the laboratory, was good. Seeder precision evaluated in the field varied in distribution patterns among seed spacings and years. Cabbage directly seeded at one seed per hill and a $30-\mathrm{cm}$ spacing produced yields and head weights similar to or higher than cabbage seeded $10 \mathrm{~cm}$ apart and thinned to 30 cm-the seeding method currently used by some commercial operators.
\end{abstract}

Establishing a full stand of field-grown plants is necessary to produce high yields of cabbage efficiently. To ensure that an adequate stand will be obtained, cabbage is generally directly seeded at a higher plant population than desired. Two to 3 weeks after planting, the stand is thinned manually to recommended within-row spacings (WRSs) of $30 \mathrm{~cm}$ (Boudreaux, 1991). Because of the high cost of hybrid seed and the shortage and expense of manual labor, any reduction in seed or thinning requirements would be an economic advantage to cabbage growers.

Research for improving stand establishment in Brassica spp. has focused on seeding for a post-thinned stand or using seed treatments to enhancegermination. Earlier, higher, and more uniform seedling emergence has been reported for many vegetable crops with fluid drilling (Gray, 1984), seed priming (Sundstrom et al., 1987), and seed hydration (Pill, 1990). Commercial acceptance of these seed treatments, however, has been low due to the specialized equipment required, the techniques' sophistication, and variable responses obtained

Received for publication 3 Feb. 1992. Accepted for publication 23 Oct. 1992. Approved for publication by the Director of the Louisiana Agricultural Experiment Station as manuscript no. 91-68-5563. We gratefully acknowledge the support of Asgrow Seed Co., Kalamazoo, Mich., in providing seed for these tests. Mention of a trademark or proprietary product is for identification only and does not imply an endorsement by the Louisiana Agricultural Experiment Station. The cost of publishing this paper was defrayed in part by the payment of page charges. Under postal regulations, this paper therefore must be hereby marked advertisement solely to indicate this fact.

'Dept. of Biology and Agricultural Engineering. ${ }^{2}$ Louisiana Cooperative Extension Service. ${ }^{3}$ Dept. of Experimental Statistics.
(Finch-Savage, 1987; Kahn and Motes, 1988, 1989; Perkins-Veazie et al., 1989). PerkinsVeazie et al. (1989) reported that desired post-thinned stands and yields could be achieved with direct-seeded cabbage under ideal and stressful conditions by using seed covers. Kahn and Motes $(1988,1989)$ determined that dry-seeded cauliflower (Brassica oleracea L. Botrytis Group) and broccoli (Brassica oleracea L. Italica Group) produced satisfactory post-thinned stand establishment and yield. Seeding broccoli at double the final spacing has been reported as an effective, low-cost grower method for stand improvement (O’Dell, 1990).

We found no literature to support the possibility of directly seeding cabbage to a final standusing precision seeding methods. Therefore, a study was initiated to determine if cabbage could be seeded to a stand without

Table 1. Seed and plant counts ${ }^{2}$ of 'Headstart' cabbage as affected by seeding spacing, Spring 1989 and 1990.

\begin{tabular}{|c|c|c|c|c|c|c|c|}
\hline \multirow{3}{*}{$\begin{array}{l}\text { Seed spacing }(\mathrm{cm}) \\
\text { and seeds }(\text { no. })\end{array}$} & \multirow{2}{*}{\multicolumn{3}{|c|}{ Seed (laboratory) (no.) }} & \multicolumn{4}{|c|}{ Plants (field) (no.) } \\
\hline & & & & \multicolumn{2}{|c|}{1989} & \multicolumn{2}{|c|}{1990} \\
\hline & Expected & Actual & Difference ${ }^{\mathrm{x}}$ & $\overline{\text { Actual }}$ & Difference $w$ & Actual & Difference $^{\mathrm{w}}$ \\
\hline 10-Thin & 35 & 29.2 & -5.7 & $25^{v}$ & -4.5 & $30^{2}$ & 0.6 \\
\hline 30-One & 11 & 13.0 & 2.0 & 8 & -4.5 & 12 & -0.7 \\
\hline 30-Two & 22 & 20.2 & -1.8 & 17 & -3.7 & 20 & 0.2 \\
\hline 20-One & 17 & 18.5 & 1.5 & 11 & -7.9 & 17 & -1.4 \\
\hline $\begin{array}{l}\text { Contrast effects } \\
\text { of seed spacings }\end{array}$ & & & & & & & \\
\hline 10-Thin vs. 30 -one & & & ** & & NS & & NS \\
\hline 10-Thin vs. 30-two & & & ** & & NS & & NS \\
\hline 10-Thin vs. 20 -one & & & ** & & ** & & $*$ \\
\hline 30-One vs. 30-two & & & $*$ & & NS & & NS \\
\hline
\end{tabular}

${ }^{2}$ Seeds counted in laboratory from $3 \mathrm{~m}$ of greased board. Plants counted 3 weeks after planting from $3 \mathrm{~m}$ of row.

yWithin-row spacings with one seed per hill of 8 to $10 \mathrm{~cm}=10$-thin, 15 to $20 \mathrm{~cm}=20$-one, and 25 to $30 \mathrm{~cm}$ $=30$-one; within-row spacings with two seeds per hill of 25 to $30 \mathrm{~cm}=30$-two.

${ }^{x}$ Difference of actual seed counts in laboratory from seed numbers expected for each seed spacing.

"Difference of actual plant counts in field from actual seed counts determined in laboratory.

v Counts made before thinning.

ws, ****Nonsignificant or significant at $P=0.05$ or 0.01 , respectively. 
counted at this time to determine actual seeding rate and for comparison with expected seeding rate.

Before any subsequent field operations during 1989 and 1990, plants were counted and distances between plants measured in the field when the plants were 5 to $8 \mathrm{~cm}$ high, $\approx 20$ days after planting (DAP). Immediately after the plants were counted and distances measured, plants in the lo-thin plots were thinned $\approx 30 \mathrm{~cm}$ apart. The thinning operation approximated the field practice of local commercial operations, and the final WRSs were not absolute.

Average air maxima/minima during stand establishment (planting date through counting date) were $25 / 12 \mathrm{C}$ in 1989 and 23/9C in 1990. Precipitation during stand establishment was $102 \mathrm{~mm}$ in 1989 and $46 \mathrm{~mm}$ in 1990. Precipitation from planting to harvest was 350 $\mathrm{mm}$ in 1989 and $367 \mathrm{~mm}$ in 1990. Supplemental sprinkler irrigations were applied on 12 and 20 Mar. and 12, 19, and 25 June 1989; and 25 Mar.; 6 and 19 Apr.; 2, 6,17, and 23 May; and 12, 18, and 29 June 1990.

Selective harvests were made over plots, so heads were harvested individually when ultimate maturity was obtained, regardless of plant population. Head maturity was determined according to the criteria described by Boudreaux (1991) and involved a manual physical assessment of head firmness. During 1989, harvests began 82 DAP on 30 May and 5, 12, and 16 June. During 1990, harvests began 78 DAP on 7 and 15 June.

Seed spacing treatments were arranged in the field in a randomized block design with four replications. Two 6-m subplots per bed were designated for data collection in the field. Four replications of each seed spacing were used when collecting laboratory data. Data were subjected to analysis of variance using the SAS general linear models procedure (SAS, 1987), with subsequent contrast comparison of seed spacing treatments with the 10-thin control. The distribution of spacing intervals was evaluated by comparing variances within and among treatments.

Seed and plant counts. Seed counts in the laboratory were less than expected for two of the seed spacings evaluated (Table 1). Differences in the number of seeds planted and plants present in the field were significantly greater in 1989 than in 1990 (P > 0.05). These differences were attributed to seedling loss due to the wetter growing conditions during 1989. Seed counts made in the laboratory and evaluated over seed spacings were highly correlated with plant counts in the field during 1989 (0.99) and 1990 (0.96). Plant counts made in the field were also highly correlated (0.98) between years.

Seed and plant spacings. Spacing uniformity varied with seed spacing, location, and year (Table 2). In 1989, plant spacing in the field was wider than seed spacing in the laboratory at all spacing treatments, Analysis of seed spacing as measured in the laboratory indicated that little variance occurred within any spacing (Fig. 1). Plant spacings in 1989 had a greater range than seed spacings in the
Table 2. Comparison of uniformity of 'Headstart' cabbage seed placement (laboratory) and plant spacing (field, 1989 and 1990) by seed spacings.

\begin{tabular}{lcccr}
\hline \hline & \multicolumn{4}{c}{$\begin{array}{c}\text { Spacing }^{x}(\mathrm{~cm}) \\
\text { and seeds (no.) }\end{array}$} \\
\cline { 2 - 5 } Location & $10-$ Thin & 30-One & 30 -Two & 20-One \\
\hline Laboratory & $10.6 \mathrm{~b}^{y}$ & $\begin{array}{c}\text { Distance between seeds } \\
26.8 \mathrm{~b}\end{array}$ & $24.3 \mathrm{c}$ & $16.8 \mathrm{c}$ \\
& & $\begin{array}{c}\text { Distance between plants } \\
42.5 \mathrm{a}\end{array}$ & $31.7 \mathrm{a}$ & $33.2 \mathrm{a}$ \\
Field, 1989 & $13.0 \mathrm{a}$ & $28.7 \mathrm{~b}$ & $27.2 \mathrm{~b}$ & $19.7 \mathrm{~b}$ \\
$\begin{array}{l}\text { Field, 1990 } \\
\text { Contrast effects } \\
\quad \text { over seed spacings }\end{array}$ & $10.6 \mathrm{~b}$ & & & \\
$\quad$ Laboratory vs. field & $* *$ & & & \\
$\quad 1989$ vs. 1990 & $* *$ & & & \\
\hline
\end{tabular}

${ }^{2}$ Within-row spacings with one seed per hill of 8 to $10 \mathrm{~cm}=10$-thin, 15 to $20 \mathrm{~cm}=20$-one, and 25 to $30 \mathrm{~cm}$ $=30$-one; within row spacings with two seeds per hill of 25 to $30 \mathrm{~cm}=30$-two.

${ }^{y}$ Mean separation within columns by least square means, $P=0.01$.

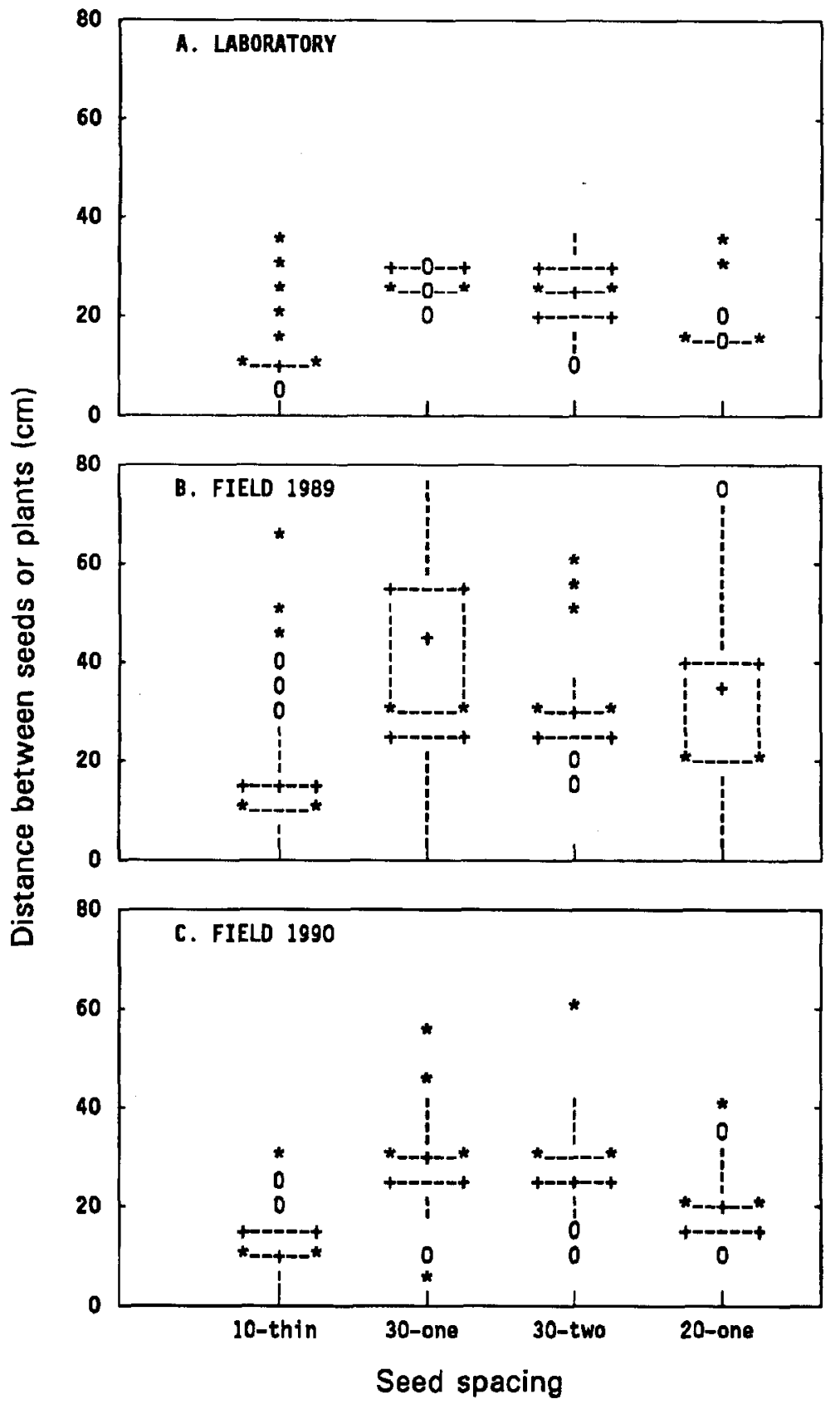

Fig. 1. Effect of seed spacing on seed distribution in the laboratory (A) and field during 1989 (B) and 1990 (C). The bottom and top edges of the box are located at the sample 25th and 75th percentiles (Tukey, 1977). The mean is indicated by the + and the median by the central dashed line ending with a $*$ within each box. The central vertical lines extend from the box as far as the data extend to a distance of 1.5 interquartile ranges, with 0 and $*$ indicating data within 3 interquartile ranges or more extreme. 
Table 3. Stand and yield characteristics of 'Headstart' cabbage in response to directly seeded spacings.

\begin{tabular}{|c|c|c|c|c|}
\hline \multirow[b]{2}{*}{ Seed spacing ${ }^{y}$} & \multicolumn{3}{|c|}{ Marketable heads } & \multirow{2}{*}{$\begin{array}{c}\text { Heads cut } \\
\text { at first } \\
\text { harvest } \\
(\%)\end{array}$} \\
\hline & $\begin{array}{c}\text { Count }^{2} \\
\text { (no./ha, 1000s) }\end{array}$ & $\begin{array}{c}\mathrm{Wt} \\
\left(\mathrm{t} \cdot \mathrm{ha}^{-1}\right)\end{array}$ & $\begin{array}{c}\text { Avg } \\
\text { head wt } \\
\text { (g) }\end{array}$ & \\
\hline \multicolumn{5}{|c|}{1989} \\
\hline 10-Thin & 50.1 & 39.8 & 790 & 24 \\
\hline 30-One & 40.4 & 40.3 & 1007 & 49 \\
\hline 30-Two & 49.7 & 37.8 & 763 & 29 \\
\hline 20-One & 38.4 & 35.4 & 947 & 48 \\
\hline \multicolumn{5}{|l|}{$\begin{array}{l}\text { Contrast effects } \\
\text { of seed spacing }\end{array}$} \\
\hline 10-Thin vs. 30 -one & * & NS & ** & * \\
\hline 10-Thin vs. 30 -two & NS & NS & NS & NS \\
\hline 10-Thin vs. 20 -one & ** & NS & $*$ & $*$ \\
\hline 30-One vs. 30-two & $* *$ & NS & $* *$ & * \\
\hline \multicolumn{5}{|l|}{ 20 } \\
\hline 10-Thin & 71.0 & 54.5 & 775 & 42 \\
\hline 30-One & 71.1 & 67.8 & 957 & 59 \\
\hline 30-Two & 82.4 & 51.0 & 625 & 36 \\
\hline 20-One & 76.0 & 49.0 & 635 & 35 \\
\hline \multirow{2}{*}{\multicolumn{5}{|c|}{$\begin{array}{l}\text { Contrast effects } \\
\text { of seed spacing }\end{array}$}} \\
\hline & & & & \\
\hline 10-Thin vs. 30 -one & NS & NS & $*$ & $*$ \\
\hline 10 -Thin vs. 30 -two & NS & Ns & NS & NS \\
\hline 10 -Thin vs. 20 -one & NS & NS & NS & NS \\
\hline 30-One vs. 30 -two & NS & * & ** & $*$ \\
\hline
\end{tabular}

${ }^{\mathrm{x}}$ Based on $3 \mathrm{~m}$ of row.

${ }^{y}$ Within-row spacings with one seed per hill of 8 to $10 \mathrm{~cm}=10$-thin, 15 to $20 \mathrm{~cm}=20$-one, and 25 to $30 \mathrm{~cm}$ $=30$-one; within-row spacings with two seeds per hill of 25 to $30 \mathrm{~cm}=30$-two.

Ns,,$* * *$ Nonsignificant or significant at $P=0.05$ or 0.01 , respectively.

laboratory or plant spacings in 1990. The larger distances between plants during 1989 were attributed to missing plants (failure to germinate and seedling diseases) and not to missing seeds. Plant spacings during 1990 closely followed expected measurements.

Yield components. Without adjusting fertilizer rates for higher plant populations, plants established at all seed spacings in 1989 produced similar weights of marketable heads per hectare, although head count per hectare varied considerably (Table 3 ). Cabbage heads that met the standards for U.S. no. 1 grade were considered marketable (Federal Register, 198 1). Marketable weight was similar for plots seeded at 30-one and those seeded at 10-thin. Average head weights were higher in plots seeded directly to the finished stand of 30-one than in the lo-thin treatment with the same fertilizer rates for all WRSs. Average head weights were also higher for plants seeded to 20 -one than plants grown at 10 -thin. At a constant fertilizer rate for various WRSs, larger cabbage heads from lower plant populations have been reported previously by Csizinszky and Schuster (1985) and Knavel and Herron (1981). Head weights also were affected by plant-to-plant variation due to greater distribution of plant spacings at 20-one and 30-one (Fig. 1). Stoffella and Fleming (1990) found that $>60 \%$ of the experimental head weight variation was associated with WRS. Cabbage plants spaced at 20-one and 30-one yielded fewer marketable heads per hectare and had a higher percentage of total yield cut at the first harvest than plants at 10-thin. Competition from adjacent plants was responsible for many undeveloped heads on cabbage planted at 30 two. Halsey et al. (1966) found that decreasing plant spacing increased the number of undeveloped cabbage heads.

The number of marketable heads for all seed spacings was higher during 1990 than 1989 (Table 3). The higher head count in 1990 caused a reduction in average head weight for plants grown at 20-one and 30-two, relative to 1989. Although plant loss normally experienced in a field planting was expected to reduce the populations, this did not occur or was not sufficient to reduce plant-to-plant variations at these spacings.

Highest yield of marketable weight per hectare was recorded on plots seeded at 30one, but these yields were not significantly different from plots seeded at lo-thin. Average head weight was heaviest from plants seeded at 30-one. Heads of 800 to $1100 \mathrm{~g}$ are the desired size in the local commercial market, so the larger size of the cabbage seeded at 30-one was considered an advantage. During the two years, $\geq 50 \%$ of the heads from the 30 one plots was cut at first harvest compared with $\approx 35 \%$ cut from cabbage seeded at 30 -two or 10-thin. Since the 10 -thin plots werethinned to simulate thinning in commercial fields, plant spacing in this treatment was not exact, and in 1990 the distance between individual plants may have been $\leq 30 \mathrm{~cm}$.

Results from these experiments indicate that cabbage can be precision-seeded to a stand without thinning. Cabbage directly seeded at 30-one produced total and average head weights similar to or higher than cabbage seeded at 10-thin-the seeding method currently used by some commercial operators. Even during the wet conditions during stand establishment in 1989, the stand and total yield of cabbage directly seeded at 30-one were equal to those of cabbage directly seeded at 10 -thin. During both years, $\approx 50 \%$ of the heads from cabbage grown at 30-one was cut at first harvest.

\section{Literature Cited}

Boudreaux, J.E. 1991. Commercial vegetable production recommendations. Louisiana Coop. Ext. Serv. Publ. 2433.

Csizinszky,A.A. and D.J. Schuster. 1985. Response of cabbage to insecticide schedule, plant spacing, and fertilizer rates. J. Amer. Soc. Hort. Sci. 110(6):888-893.

Federal Register. 1981. United States standards for grades of cabbage. 46 FR 63203.

Finch-Savage, W.E. 1987. The potential for seed, sowing, and seedbed preparation treatments to improve the production of uniformly-sized carrot roots for processing. Acta Hort. 220:181188.

Gray, D. 1984. The role of fluid drilling in plant establishment. Ann. Applied Biol. 7:153-171.

Halsey, L.H., J.F. Beeman, D.R. Hensel, W.W. Deen, and V.L. Guzman. 1966. Influence of variety and spacing on yields of cabbage from a single harvest. Proc. Florida State Hort. Soc. 79:194-201.

Kahn, B.A. and J.E. Motes. 1988. Comparison of fluid drilling with conventional planting methods for stand establishment and yield of spring and fall broccoli crops. J. Amer. Soc. Hort. Sci. 113(5):670-674

Kahn, B.A. and J.E. Motes. 1989. Comparison of fluid drilling with conventional planting methods for stand establishment and yield of spring and fall cauliflower crops. J. Amer. Soc. Hort. Sci. 114(2):200-204.

Knavel, D.E. and J.W. Herron. 1981. Influence of tillage system, plant spacing, and nitrogen on head weight, yield, and nutrient concentration of spring cabbage. J. Amer. Soc. Hort. Sci. 106(5):540-545.

O'Dell, C. 1990. Improving broccoli stands. Amer. Veg. Grower 38(1):25-27.

Parish, R.L., R.P. Bracy, and W.A. Mulkey. 1989. A precision cultural system for vegetables in Louisiana. Amer. Soc. Agr. Eng. Paper 89-1566.

Perkins-Veazie, P.M.,D.J. Cantliffe, and J.M. White. 1989. Improved stand establishment of direct-seeded cabbage with seed covers. J. Amer. Soc. Hort. Sci. 114(1):36-39.

Pill, W.G. 1990. Seedling emergence and yield from hydrated collard seeds fluid-drilled in high-phosphorus gel. HortScience 25(12):1589-1592.

SAS. 1987. SAS/STAT guide for personal computers. version 6. SAS Inst., Cary, NC.

Stoffella, P.J. and M.F. Fleming. 1990. Plant population influences yield variability of cabbage. J. Amer. Soc. Hort. Sci. 115(5):708-711.

Sundstrom. F.J.. R.B. Reader, and R.L. Edwards. 1987. Effect of seed treatment and planting methods on tabasco pepper. J. Amer. Soc. Hort. Sci. 112(4):641-644.

Tukey, J.W. 1977. Exploratory data analysis. Addison-Wesley, Reading, Mass. 